\title{
Draft of a Note for RunNing Away from Home
}

All winter the sun hung like an unglazed light bulb dead center in a quonset hut. How the somewhere else

of this place gets spelled out: in the contrail of an ascending jet, as white as

an old scar, angled between the muscular brick forearm

of a Presbyterian church steeple and the worn-thin dime of another full moon in daytime.

The usual agencies argue for departure: New York City grinds its jaws in our direction,

and after her old California address turned up again,

the thought of it snoozed like a burglar gun next to my sleeping left ear.

First, an apparatus of purpose. Then bye-bye. 